\title{
Implementing the Balanced Scorecard in Public Organization: An Experience in Communication Affairs Bureau Dire Dawa Administration, Ethiopia
}

\author{
ESYAS DEBEL GELAN \\ (MBA in Business Administration) Dire Dawa, Ethiopia PO Box: 230, Dire Dawa, Ethiopia
}

\begin{abstract}
The Balanced Scorecard (BSC), first created by Kaplan and Norton in 1992, has been developed over the last 28 years, gaining attention all over the world. In Ethiopia context ministry of civil service in 2010.The introduction of Civil Service Reform program (CSRP), as part of the 14 national capacity building programs, was in response to weaknesses in the organizational structure and the public service delivery and to simulate the overall development effort of the country. That the emergence of the Public Sector Capacity Building Program (PSCBP). It has laid the foundation for different capacity building programs with the objective of improving the scale, responsiveness and efficiency of public service delivery and promoting good governance both at a federal, regional and local level.(Rashed Ul Hasan, 2017, Mesfin, 2009 and MoFED, 2012)Government Communication Affairs Bureau is one of the public service institutions in the Dire Dawa city that implemented the BSC with the notion of improving its overall organizational performance. The point of this study is to analyze the key impact of successes and failure factors of the execution processes of Balance Scorecard: - for improvement of strategic planning \& performance measurement in Dire Dawa Administration Communication Affairs Bureau.The study used a qualitative research method. The data for this study was obtained through questionnaires that were distributed to 84 management members and non-management employees of the bureau in which only 82 were fully completed and returned. The sample was selected based on stratified random sampling the questionnaire was distributed to the staff members on the stratified based on their department. The data collected were analyzed using SPSS and Microsoft Excel.The result of this study will be providing valuable inputs and directions have been maintained with regard to the bureau vision, mission, and strategy; while other activities. The study may also use as a point of reference for others who want to conduct further study on the same issue.
\end{abstract}

Keywords: Balance Scorecard, Performance Measurement, Evaluation

DOI: $10.7176 / \mathrm{PPAR} / 10-5-01$

Publication date:May $31^{\text {st }} 2020$

\section{Introduction}

\section{- Background of the Study}

The recent wave of global political and economic integration and increased concerns about standardized and customer- tailored service delivery activities have posed challenges on firms all around the world which, in turn, led to an increased focus on competition through more flexible, customer-oriented, prompt and up to date services as a driving force for improved productivity and enhanced overall organizational performance.

Nowadays, organizations are used both financial and non-financial instruments so as to achieve a progressive change. Reforms throughout the globe are conducted with variation in accordance with the expectation of government policies and strategies. Not only the internal forces are fostering changes but also international external forces are playing an important role. Ethiopia is not free from this as requests came from different stakeholders to reform the government system to make it consistent with economic growth. The democratization process also demanded implementation changes that foster in promoting good governance in the country.

The needs to satisfy the citizen expectation with the changing political and economic environment call for policymakers' attention. Particularly making the public service delivery process efficient and effective is a timely demand to cope with the ever-changing political and administrative dynamics. The increasing pressure as a product of globalization is forcing the country to take serious reform measures to overhaul the service delivery process in a bid to fight poverty and achieve greater overall development.

The public sector performance, which is measured in terms of how efficiently and effectively it achieves its mission, is believed to play a vital role in the development of an economy since it impacts the effectiveness of the private sectors. The concept of the new public management and public sector pressure for administration excellence called for the need to apply Business Process Reengineering (BPR) while Balance Scorecard (BSC) gets popular a holistic approach for planning and performance measurement. In light of this, these two reform tools have been adopted and implemented by Ethiopian public institutions in general and the Dire Dawa administration in particular for the last six years.

In line with this, much policy and implementation attention were given to Business Process Reengineering (BPR) and Balance Scorecard (BSC). It has been implemented in all bureaus and other government structures of 
Dire Dawa administration for a reasonably long period of time. Measuring the impact and learning from the previous implementation is very critical to document the changes the reforms has brought, identify which desires outcomes have obtained and which are not and why, and more importantly take corrective measures including recalibrating the BPR to make the implementation of these reforms more effective. Given different programs are simultaneously implemented to improve the public sector, counting or measuring the impacts only attributed to the BPR and BSC implementation either separately or as a package requires sophisticated impact evaluation techniques.

This study is initiated to analyze the extent to which the intended objectives of BSC an implementation that is; Balance Scorecard is a management system that enables organizations to clarify their vision and strategy and translate them into action has been achieved and pinpoint assess the practice and the challenges of Balanced Scorecard implementation and possible solution to solve the challenge factors in Dire Dawa Government Communication Affairs Bureau.

\section{- Statement of the Problem}

The city government was highly motivated to sustain the initiated strategic reform programs in all civil service public sectors including the Communication Affairs Bureau. In this lens, strongly supportive and continues to follow up supervision programs was taken by the Civil Service Bureau with Dire Dawa Administration Council Standing Committee officials to enhance the progress of the implementation of BPR and BSC with the aim of effective execution of the reform programs. However, the result of the feedback depicted that there was remarkable progress is some institutions, whereas some sectors were lagging behind that of others./Source, from civil service reform follow up office report of 2017/.

The other challenge associated with BSC implementation is leadership and the manager's commitment. Artley et al, (2001) stated that without strong leadership a program won't succeed leadership must be dedicated to the program all the time. This indicated that commitment is very important in managing institutional achievement. So those who involved in a leadership position need to be committed to the program. The degrees of commitment will determine its degree of success in many organizations, leadership commitment to the development and use of performance measures is a critical element for organizational successes. Employee perception is among the factors that can influence an effective performance management system. Habtamu (2005) noted that employee in the organization must be able to trust two sets of people-their leadership and each other's, He also added that poor trust results in inequality, which can be expressed in various ways. This reveals that such kind of discrimination could affect the perception of employees in an institution towards their managers/leaders.

Finally, communication is a critical tool for establishing and maintaining a performance management system. A good communication process also helps to provide a critical link between the task, employee performance, and corporate strategic plan/measures. The two most effective method of communication is meetings and institutional publications. These methods can hold the attention of the employees in them long enough to provide a thorough explanation (Artery and Stroh, 2001). Having been through the difficult process of formulating a strategy, the organization needs to ensure that it has a systematic method for translating its newly developed strategy into operational objectives and measures.

This research will assess the implementation of a balanced scorecard, whether it is going according to the planned goals by giving due attention to the Government Communication Affairs Bureau aspect. Hence this paper has been investigated the existing impact of the balanced scorecard and recommends an appropriate improvement that enables a balanced scorecard successfully.

\section{Research Questions}

In line with aforementioned objectives, the research will address the following research questions are deemed valuable for the study

1. What are the impacts brought by the implementation of BSC in public organizations under Government Communication Affairs Bureau?

2. Does the performance of public organizations improved as a result of the implementation of BSC? If so, how significant is it?

3. What are the major bottlenecks to implement BSC in a bureau or under study what are the possible solutions to tackle them?

\section{Objectives of the Study}

General objective

The main objective of this study is to the impact of the Balanced Scorecard and its relationship to the improvement of strategic planning performance measurement in service rendering the case of public organization for the existing responsiveness $\&$ efficiency of public service delivery and promoting good governance. 


\section{Specific Objectives}

The objectives of this study were to:

1. To investigate how leaders manage BSC implementation and know their effectiveness.

2. To measure how organizations give attention to Performance monitoring, evaluation and feedback systems of the strategic objective.

3. To identify and evaluate the current employees' attitude towards BSC implementation processes in the sector.

4. To identify the key successes and failure factors that affect BSC implementation.

5. To identify the effectiveness of BSC implementation for the improvement of performance evaluation.

6. To recommend the short term and long term solution based on their severity of the identified challenges in order to make the BSC system sustainable, efficient and effective for improvement of planning and performance measurement.

\section{REVIEW OF RELATED LITERATURE}

\section{The Origins of the Balanced Scorecard}

The Balanced Scorecard was developed by two men, Robert Kaplan, a professor at Harvard University, and David Norton, a consultant also from the Boston area. In 1990, Kaplan and Norton led a research study of a dozen companies exploring new methods of performance measurement. The impetus for the study was a growing belief that financial measures of performance were ineffective for the modern business enterprise (Niven, 2002).

According to Kaplan (2010), the concept of the performance measurement using both financial and nonfinancial metrics dates back to 1950s when General Electronics (GE) Company introduced these two parameters to measure divisional performance for its business lines before it took its current form. As Kaplan notes that, in the corporate of G.E staff members practiced a project to maximize the performance tools for decentralized general electronics unit of business. As the team of the members of the project announced (recommended) that divisional productivity can be measured by seven of non financial such as productivity, product leadership, market share, employee attitude, and personnel development, in the case of one financial matrix the profitability was stated by Kaplan, (2010, P, 5).

As the traditional industry performance measurement systems mainly relied on financial information, they were subject to criticisms for ignoring other intangible assets which are critical drivers of future financial performance, and hence lack the ability to track overall organizational performance. BSCs are used extensively in business and industry, government, and nonprofit organizations worldwide.

Gartner Group suggests that over $50 \%$ of large US firms have adopted the BSC. More than half of major companies in the US, Europe, and Asia are using BSC, with use growing in those areas as well as in the Middle East and Africa. A recent global study by Bain \& Co-listed Balanced Scorecard fifth on its top ten most widely used management tools around the world (BSI, 2019).

\section{The Evolution of the Balanced Scorecard}

The Balanced Scorecard has significantly evolved from its early stage as a simple financial and non-financial performance measurement framework to holistic strategic planning, management, and execution tool of organizational strategies. The main reason for the evolution was due to empirical evidence of shortcomings found in preceding generations and the resulting growing criticisms by academicians, authors, and management consultants.

However, until the 1990s, majority of companies was used primary management system in order to used exclusive financial information as well as highly relied on a budget to keep giving special attention on the performance short-run activities (Kaplan, 2010, p.7).

On the other hand, the use of financial information alone for organizational performance measurement was increasingly criticized by many authors throughout 1980s to 1990s.

According to Czekaj and Świerk (2009 and 2010), the evolution of BSC is represented by four generations: in the early 1990-1993 - originally the balanced scorecard was developed to measure the company's performance in four themes of the organization: finance, customers, internal processes and learning and growth.(i.e using the four perspectives); The first generation of the balanced scorecard was a set of metrics that served managers to make an overall assessment of the activity of the organization;

In the 1994-1996 - the second generation of the balanced scorecard consists of treating the concept as a comprehensive system for managing the organization in the strategic and operational dimensions. This way of using the balanced scorecard helps organizations develop the organization's strategy and present it to all employees in order to synchronize all the activities of the organization with the strategy being realized;

In the 2000-03 - the third generation of the balanced scorecard designs is extended by the so-called strategy map. With the map it was possible to visualize the strategy and the occurring cause-and-effect relationships between its various components, which enable employees to understand the relationship between their own work 
and the objectives of the company; since 2004 until today - the balanced scorecard has transformed into a model of organizational synergy. The creators of the balanced scorecard keep expanding the concept in the learning and growth perspective, with an emphasis on the measurement of strategic readiness of intangible assets.

\section{The Concept of Balanced Scorecard}

The traditional mode of evaluating an organization's performance was primarily based on financial aspects: profitability through increased revenues \& reduced costs and other financial analysis techniques such as return on assets (ROA), return on Investment (ROI), profit margin etc. As a result, such measures of organizational performance were criticized by many authors and management consultants for being: short term oriented, considering past performance, being non-consistent with current business's environment, focusing on tangible assets, and lacking predictive power.

According to Kaplan and Norton (1992), this traditional accounting performance measurement method neither provides appropriate and adequate guidance for organizations to take in the future nor satisfy the needs of stakeholders in today's dynamic and competitive environment. Further, they have pointed out those accountingbased measures: first, are too historical; second, lack predictive power; third, reward the wrong behavior; fourth, focus on inputs and not outputs; fifth, don't catch up the main business changes up to be late sixth, forward the practices, don't cross-functional system in the company. Finally, the seventh one provides inefficient attention that is difficult to identify resources especially that of intellectual capital resources. Intangible assets such as employee knowledge, customer satisfaction and loyalty, innovation, environmental competitiveness, research and development, productivity, and other important company-specific factors are the key to success in achieving overall organizational performance in today's economy.

Thomas Stewart (cited in Niven, 2006, p.5), has strongly supported this idea as-the most important of all are soft 'assets such as skills, capabilities, expertise, cultures, and loyalties and so on. These are the knowledge assets - intellectual capital - and they determine success or failure. However, Ruben (1999) notes that accountingbased measures (lag indicators) are unable to capture such key elements of an organization.

Thus, due to the growing criticism on the use of such financial measures as an organizational performance measurement system, researchers and academicians had exerted their effort to develop more sound approaches to measure performance. It was in 1992 that Kaplan and Norton introduced the Balanced Scorecard (after they made an extensive study with a number of companies since 1990) which considers financial, and non-financial metrics as a measurement of overall performance of an organization. Since then, BSC has become very popular and attracted considerable interest among academics, practitioners, firms, organizations, and others all over the world.

Each of these four constitutes of the BSC has own value to be addressed such as Financial perspectives major intention is insight into surviving, succeed and prosper of business; customers perspective considers the yield of the business from value creation and making difference among existing and new entrants of the firm to the market environment; internal process critical assumption is that the developed product/service has the best satisfaction with its competitors in order to cope up with the complexity of the public institution; and the other learning and growth ambition will rely on creation of continues improvement in the system to sustain the desired wish of the customers, employees, shareholder and stakeholder, and establish suitable climate that assists the introduced change in the business (Fentahun, 2007). Financial measures have numerous potential to portray the value of the rear aspect of the accomplishment scenario in the business arena which is critically an indication of lagging view in the sector. Whereas it has not had the ability to show the future situation of the organization success that is a weak prediction power in the dynamic business context (Niven, 2002).

Figure 2.1 Lagging and Leading Performance Measures

\begin{tabular}{|c|c|c|c|}
\hline S/No & $\begin{array}{l}\text { Comparison } \\
\text { on points }\end{array}$ & Lagging & Leading \\
\hline 1 & Definition & $\begin{array}{l}\text { Measures focusing on the result at the } \\
\text { end of a time period, normally } \\
\text { characterizing historical performance }\end{array}$ & $\begin{array}{l}\text { Measures that"drive"to } \\
\text { performance lag measures, } \\
\text { normally measuring intermediate } \\
\text { processes and activities. }\end{array}$ \\
\hline 2 & Example & $\begin{array}{l}\text { Market share } \\
\text { Sales } \\
\text { Employee satisfaction }\end{array}$ & $\begin{array}{l}\text { Hours spent with customers } \\
\text { Proposal written } \\
\text { Absenteeism }\end{array}$ \\
\hline 3 & Advantages & Normally easy to identify and capture & $\begin{array}{l}\text { Predictive in nature, and allow the } \\
\text { organization to make adjustment } \\
\text { based on result }\end{array}$ \\
\hline 4 & Issues & $\begin{array}{l}\text { Historical in nature and do not reflect } \\
\text { current activities; lack predictive power }\end{array}$ & $\begin{array}{l}\text { May prove difficult to identify and } \\
\text { capture; often new measures with } \\
\text { no history at the organization }\end{array}$ \\
\hline
\end{tabular}

Source: Niven, 2002:116 


\section{The Balanced Scorecard Four Perspectives}

The Balanced Scorecard is, therefore, a multi-dimensional and broad set of measure that is related to the important parts of an organization, mostly structured into four perspectives. These set of measures are integrated across the functional boundaries and developed in line with the strategy and mission of the organization. The four perspectives developed by Norton and Kaplan are discussed here below:

\section{Financial Perspective \\ $\Rightarrow$ How Do We Look to Share Holders?}

Financial measures indicate whether the company's strategy implementation and execution are contributing to the bottom line improvementll (Kaplan and Norton, 1992, p.77). According to Paul R.Niven (2006), the Financial Perspective focuses on measures which have the goal of enhancing shareholder value. Possible performance measures under this perspective are derived from the objectives of revenue growth and productivity which include profitability, cost/unit, revenue growth, asset utilization etc.

Niven (2006), also states that focusing resources, energy, and capabilities on customer satisfaction, quality, knowledge, and other factors in the rest of the perspectives without incorporating indicators showing the financial returns of an organization may produce little added value.

\section{Customer Perspective \\ $\Rightarrow$ How Do Customers See Us?}

The customer dimension of the Scorecard contains several cores or general measures which include a high degree of satisfaction of clients, customer retention, attraction (acquisition) of new clients and market share etc.

According to Kaplan and Norton (1996), the objective of an organization with this perspective is to identify the customer and market segments in which the organization will compete and, accordingly, the measures to track related performances. This enables an organization to identify and focus on factors that are really important in meeting customers 'demands.

Niven (2006) also notes that to achieve positive financial results, organizations need to create and deliver products and services which customers perceive as adding value to them. He remarks that the measures in the customer perspective should answer three basic questions: What are our target groups of customers? What do they expect or demand from us? What would the value proposition for us be in serving them?

According to Kaplan and Norton (2000), the value proposition may be chosen within three differentiators:

- Operational excellence - focus on low price and convenience;

- Product leadership - offer the best product in the market;

- Customer intimacy - focus on long-term customer relationship through a deep knowledge of their needs.

Niven (2006), also states that the most common measures for this perspective include: customer satisfaction, customer loyalty, and market share.

\section{Internal Business Process Perspective \\ What Must We Excel at?}

The internal business process perspective of the BSC mainly emphasizes that organizations must control important working conditions or inner process that may create value to customers and shareholders. For an organization to be effective in performance, the internal working process and systems should be as excellent as possible in assisting operational units to provide values to attract and retain clients of the market.

Kaplan and Norton (1992), presume that great customer performance is the result of processes, decisions, and actions which managers need to focus on in order to satisfy customers 'needs. This perspective measures business processes that need to play a key role to increase customer satisfaction.

Niven (2006), highlighted that this perspective measures an organization's performance with respect to speed (on-time delivery, process cycle time, customer response time etc), quality (continual improvement, rework, repair and scrap, process capability etc), Measures of cost (costs of waste, cost per transaction etc) and other measures (floor space utilization, forecasting and planning accuracy etc).

\section{Growing and Learning of Perspective}

\section{We would be able to Continues Improvement and Create Values?}

This perspective answers the fundamental question to achieve our targets and accomplish core activities, how must we learn, communicate \& work together? 'And it is the establishment whereupon the balanced scorecard is constructed. Niven (2006) notes that measures of the Learning and Growth perspective are the enablers of the other perspectives, it also emphasizes that awareness, employee aptitudes, and fulfillment, the accessibility of information and adequate tools are often the source of growth and along these lines the most common measures of this perspective. Organizational learning and development come from three principal sources: people, systems, and organizational procedures...businesses will have to invest in reskilling employees, enhancing information technology and systems, and aligning organizational procedures and routines (Kaplan and Norton, 1996, pp.2829). 
Figure 2.2 Framework and Perspectives of BSC

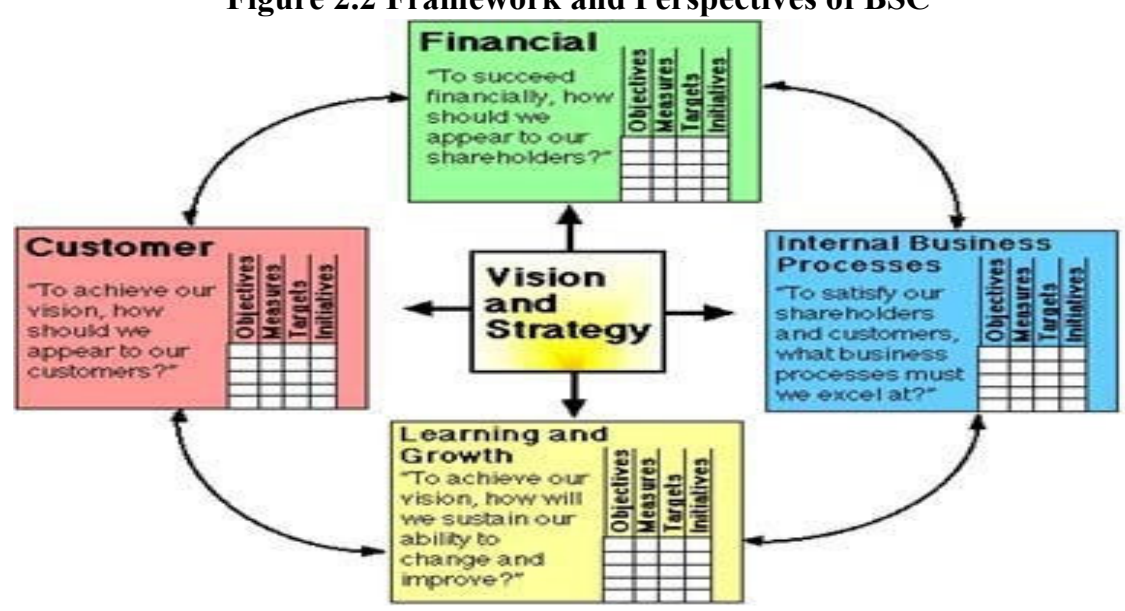

Source: Kaplan \& Norton, 1996: 9.

As we clearly view the figure: 1 reveals that objects and measures of a tool inherit from the institution's vision and strategy with an optimistic outlook on pillars. Due to the pillars serve as a framework for the balanced scorecard (Kaplan and Norton, 1996:8)

\section{Public Sectors and Balanced Scorecard}

"The balanced scorecard (BSC) was originally developed for the private sector as a means of clarifying and updating strategy, communicating strategy in the company, aligning unit and individual goals to strategy, linking objectives to long term targets and budgets, and conducting performance reviews to improve strategy" (Kaplan and Norton 2001a); and it is now also being used as '... a powerful tool for rapid and effective strategy implementation' (Kaplan and Norton 2005). However, in the last decade, the balanced scorecard's multidimensional focus has also been viewed as a way of addressing the need for a strategic performance measurement system within public sector organizations (Umashev and Willet 2008).

A public organization that knows its strategy of operation and possesses identified key themes, within which it tries to achieve perfection, can commence the process of the creation of the balanced scorecard. The improvement of the balanced scorecard consists of the following basic steps (Rohm 2002, p. 2): strategic analysis, identification of customers and value proposition for them; defining the vision and mission statements;

defining the strategy/strategic themes; defining perspectives and strategic objectives; creating a strategic map, targets and measures of their achievements; developing strategic initiatives for specific areas of activity; cascading balanced scorecards at lower organizational levels; analyzing the results of activities and undertaking corrective action.

Balanced Scorecard is an instrument to leadership art to sustain its conceived ideas or new scheme in the fluctuating business environment to cope up with change. Because it facilitates a communication system among leaders and employees about the change occurred due to the advancement of the information system, accelerated demand of citizens to public service, globalization and so on. Hence it is a critical desired instrument for leaders in order to break through the status quo (Stemsrud Hagen, 2003).

To translate the strategy of the organization into action, all concerned bodies must sense it as their own aim to attain. So, it requires the effort of leaders in communicating the strategy with their followers through BSC (Kaplan and Norton, 2001).

Effective implementation of BSC in the organization tries to link performance management programs with its strategic goals and tactical objectives that scale up the concept of the balanced scorecard. Thus, exercising the technique becomes so difficult when critical care is not taken by everybody in the organizational community. That why the coiners give attention to the excursion parts and based on this issue Kaplan and Norton (2008) argued that implementation stage must be adapted in six stages in simultaneously with integrating strategic planning and operational execution in a closed loop manner.

In general to sum up the whole implementation process, BSC is not a straightjacket there are various factors that hamper effective execution. The basic challenges of the implementation process of BSC are varied from context to context but Richardson (2011) clearly identifies the subsequent factors which are highly threatening the execution process of BSC in the organization such as:-

- lack of visionary leadership, inactive senior executives commitment, and involvement in the process BSC

- Most organizations do not communicate BSC throughout the entire organization

- Undermining its essence and allocation of few resources 
- Considering it as a correction mechanism

- Attention is not given to the indicators of BSC as change desires in the system

- Few vital indicators are not addressed

- Implementing BSC for a reason

- No clear linkage between indicators

- Employees are do not participated in the development stage of the BSC

\section{RESEARCH METHODOLOGY}

\section{- Research Design}

The research design that was applied to this study was a descriptive research design. In order to develop a snapshot of particular situation, descriptive research was used. It involves large samples which are used to give a description of an event or define attitude, options or behaviors that are measured or observed in a particular environment (Mcnabb, 2002).The most distinguishing feature of this methodology was that the researcher had no control over the variables. Since the objective of the study is to uncover balanced scorecard implementation and its possible challenges at GCAB, the descriptive design was most appropriate (C.r. Kothari 2004).

- Sources of Data

This study will make use of mainly through both primary and secondary data in its construction. Essential information was collected through a survey method by using standard questionnaires that were arranged in 5-point Likert's scale. The secondary sources of data for the study include published books, journals, articles and relevant documents (documents related to the study) have also been extensively reviewed as references.

\section{- Research Instrument /Tools}

"A structured questionnaire arranged in standardized 5-point Likert's scale was chosen because of the strengths of this method. A structured questionnaire allows all the participants to respond to the same questions, as participants are offered the same options on each statement and it provides an efficient way of collecting responses from a large sample"(Anol, 2012). The "Closed-ended questionnaire also provides confidentiality to the respondents to enable them to complete the questionnaire honestly; and its use also tends to increase the response rate" (Khomba, 2011). That is why the researcher chooses a Likert scale survey questionnaire as the main instrument to gather quantitative data for this study. The study targeted to management member and non- managements in GCAB, with the focus on measurement, Practice, and Challenges in Balanced scorecard implementation in the Bureau, It was necessary to tailor the questionnaire to make it as user-friendly as possible. In order to so, the researcher prepared statements and interval settings based on the Likert- style rating scales to which the participants (Management/Non-managements) had to respond (with the rankings signifying the degree of agreement, ranging from a scale of $-1 \|$ referring to - strongly Disagree $\|$ to a scale of $-5 \|$ referring to - Strongly Agree $\|$ on a five-point rating scale).The main steps that were followed when formulating the questionnaire included the identification and generation of perspectives surrounding the intended thematic area, review of similar questionnaires that were used in prior surveys. All these culminated in the formulation of 19 questions that represent the main areas of the study.

The researcher used one major research instruments and questionnaire close-ended questions only. Meanwhile, whether to ask a question in an open or closed format is one of the most significant considerations for many researchers. In this research, a self-completion questionnaire with closed questions was developed. The selfcompletion questionnaire is very familiar method of business research, and the research instrument. According to Bryman and Bell, (2003) closed questions have some advantages: it is easy to process answers; it enhances the comparability of answers, and makes them easier to show the relationship between variables. It is better than open question for this research.

\section{- Sampling Method and Sample Size Determination}

\section{Sampling Method}

In selecting the research subjects, stratified random sampling will be used. Because Stratified random sampling helps for a population from which a sample is to be drawn does not constitute a homogeneous group, a stratified sampling techniques is generally applied in order to obtain a representative sample." The rationale for applying the simple random sampling was aimed to have an equal probability of selection for the entire population." (Anol, 2012).

\section{Target Population}

The target for the survey questionnaire includes management members and non-management who have worked for or more than a year in the GCAB was included in the pool as recently recruited employees may not have deep knowledge of the benefits and root causes of impact of BSC implementation in the Bureau. Therefore, the number of permanent workers in each department is summarized in the table below. 
Table 3.1 Total Population Each Department

\begin{tabular}{|c|l|c|c|c|}
\hline No & \multicolumn{1}{|c|}{ Department } & Malee & Female & Total \\
\hline $\mathbf{1}$ & Management members & 4 & 3 & 7 \\
\hline $\mathbf{2}$ & BSC implementation team & 4 & 1 & 5 \\
\hline $\mathbf{3}$ & Information communication Directorate & \multicolumn{2}{|c|}{} \\
\hline \multirow{2}{*}{} & Electronics media Team & 15 & 5 & 20 \\
\cline { 2 - 5 } & Press media Team & 12 & 6 & 18 \\
\cline { 2 - 5 } & Web site Team & 7 & 3 & 10 \\
\hline $\mathbf{4}$ & Information Centers Empowerment and Development Directorate & & \\
\hline \multirow{2}{*}{} & Event creation Team & 9 & 9 & 18 \\
\cline { 2 - 5 } & Research and Training Team & 8 & 7 & 15 \\
\hline $\mathbf{5}$ & Human Resource Management Department & 4 & 2 & 6 \\
\hline $\mathbf{6}$ & Budget and finance Department & 3 & 5 & 8 \\
\hline \hline \multicolumn{2}{|c|}{ Total } & & $\mathbf{1 0 7}$ \\
\hline
\end{tabular}

Source: Summarized from all Department. GCAB HRM, December, 2019

\section{Sampling Size}

The study population will staff who work in the Government Communication Affairs Bureau on a permanent basis who is around 107 in number. Krejcie and Morgan's (1970) published a formula for an efficient method of determining a representative sample size of a given population using the following formula. Thus, in the present study, the sample size was determined by using this formula.

Where:

$$
s=\frac{x^{2}(N p(1-P)}{\mathrm{D}^{2}(\mathrm{~N}-1)+x^{2} \mathrm{P}(1-\mathrm{P})}
$$

$\mathrm{S}=$ required sample size

$\mathrm{X} 2=$ the table value of $95 \%$ confidence interval

$\mathrm{P}=$ the population proportion (assumed to be 0.5 for it provides the maximum sample size)

$\mathrm{D}=$ the degree of accuracy expressed as a proportion $(0.05)$

$\mathrm{N}=$ the population size

Hence, in this study

$\mathrm{X} 2=1.96 \mathrm{~N}=107$

$\mathrm{D} 2=0.05 \quad \mathrm{P}=0.5$

$=\frac{(1.96)^{2}(107)(0.5)(1-0.5)}{0.05^{2}(107-1)+(1.96)^{2}(0.5)(1-05)}$

$s=\frac{102.76}{1.2254}$

$$
=\frac{(3.8416)(53.3)(0.5)}{0.0025(106)+(3.8416)(0.5)(0.5)}
$$

$s=83.85$

Therefore, the result of the equation was 83.85 and approximately 84 representative samples were taken from 107 population size for the questionnaire survey. 
Table 3.2 proportional stratified sample

\begin{tabular}{|c|c|c|c|}
\hline No & Variable & Population Size & Sample Size \\
\hline 1 & Management members & 7 & 6 \\
\hline 2 & BSC implementation team & 5 & 4 \\
\hline \multirow[t]{4}{*}{3} & Information communication Directorate & & \\
\hline & Electronics media Team & 20 & 16 \\
\hline & Press media Team & 18 & 14 \\
\hline & Web site Team & 10 & 8 \\
\hline \multirow[t]{3}{*}{4} & Information Centers Empowerment and Development Directorate & & \\
\hline & Event creation Team & 18 & 14 \\
\hline & Research and Training Team & 15 & 11 \\
\hline 5 & Human Resource Department & 6 & 5 \\
\hline 6 & Budget and finance Department & 8 & 6 \\
\hline \multicolumn{2}{|r|}{ Total } & 107 & 84 \\
\hline
\end{tabular}

Source: Survey Result (2019)

- Method of Data Analysis

The researcher will analyze the data gathered through close-ended questionnaires with the aid of SPSS (Statistical Package for Social Science) version (20) which consists of descriptive statistics in terms of mean, median, mode standard deviation. In addition, the findings of the study are categorized and presented under thematic areas and analyzed using different descriptive statistical tools such as graphs, pie charts, tables and percentages accompanied by supporting qualitative information. Software Package for Social Sciences (SPSS) was applied in analyzing the data.

\section{Reliability Test}

For this examination, in order to measure or evaluate the internal consistency of variables Cronbach's alpha was utilized. Attach to that Cronbach's alpha was reliability coefficient which is used to measure the consistency of the variables of scale that represents a number of ranges from 0 and 1 were noted by Zikmund et al., (2010) from the above measurement the scales the generally accepted rule tamp was of 0.7 which indicates fair reliability.

In this case, the researcher was applying Cronbach's alpha that gets the range of greater than 0.7. That means it is accepted as shown in table 3.6.2 the reliability test runs for the questionnaire of the study showed Cronbach's alpha of $0.89,0.76,0.87$ and 0.85 for BSC implementation, BSC for strategy execution \& communication tool, Performance measurement schedule analysis and challenges of BSC implementation in GCAB respectively indicating an acceptable internal consistency.

\section{Cronbach's Alpha Coefficient}

Questionnaire category

\begin{tabular}{lll}
\hline Balance scorecard implementation & .891 & 8 \\
BSC for strategy execution \& communication tool & .769 & 3 \\
Performance measurement schedule analysis & .871 & 3 \\
\hline Challenges of BSC implementation in GCAB & .857 & 5 \\
\hline
\end{tabular}

Source: SPSS

\section{RESULTS AND DISCUSSIONS}

- $\quad$ Response rate

Table 4.1: Response rate

\begin{tabular}{lcc}
\hline Participants & Frequency & Percentage \\
\hline Responded & $\mathbf{8 2}$ & $\mathbf{9 8}$ \\
Non responded & $\mathbf{2}$ & $\mathbf{2}$ \\
Total & $\mathbf{8 4}$ & $\mathbf{1 0 0}$ \\
\hline
\end{tabular}

Source: Survey 2019

As indicated in table 4.1 above, Out of 84 samples, 82 questionnaires were returned fully completed, which consists of $98 \%$ of the total. Two of the respondents failed to return the questionnaires giving a response rate of $2 \%$.

\section{- Respondents' Profile}

In this section, the researcher analyzed the respondent's profile, which includes gender, age, and educational level, position, department and years of experience of respondents who were involved in this study. As indicated in table 4.2, from the total 84 respondents, $61 \%(\mathrm{~N} \mathrm{50)}$ were male respondent and $39 \%(\mathrm{~N}=32)$ respondents were found to be female as the result. This presupposes the generals, the margin between males and females more dominated by males. The results showed by SPSS that, the largest proportion of the respondents falls on the age of the group 
between ranges $26-35$ years, which is $56 \%$ (46), followed by the second largest proportion of the respondents aged between $36-45$ years, which is $23 \%$ (19). The third-largest proportion of the age group is between 20-25 years, which is $10 \%(8)$, followed by an age group less than 25 years, which is also $7 \%$ (6) and above 45 years is $4 \%$ (3). It can conclude that the majority of the respondents were aged between 26-45 years. The data collected showed that academic qualification. The largest proportion of the respondents, which is $80.5 \%(66)$ of them had attained bachelor's degree and the second largest proportion of the respondents, which is $11 \%$ (9) Diploma or certificates in TVET college and the third-largest proportion of the respondents, which is $8.5 \%$ (7) holds postgraduate Degree and above. The majority of the participants in the study are proficient individuals who have already accomplished different levels of education. The respondents are accomplished who are accepted to be capable and familiar with practice issues related to BSC. The collected data shows that the highest percentage of the respondents, which is $44 \%$ (36), served the organization 1 up to 5 years. The second-largest percentage of respondents, which is $30 \%(25)$, worked for 6-10 years, the rest were $26 \%$ (21) with service years of more than 10 years. From this one can conclude that more than $80 \%$ of respondents are worked in their activity for over 2 years. The respondents are all around experienced and it's accepted to ponder BSC structure progressively over expertly. The final collected show that hierarchical position in the organization. The smallest percentage of the respondents, which is $7 \%(6)$ of the respondents are from the management members and the highest percentage of the respondents, which is $93 \%$ (76) are non management members of the Bureau.

Table 4.2: Summary of Profiles of Respondents

\begin{tabular}{|c|c|c|c|c|}
\hline Variable & Categories & $\mathbf{N}$ & n & $\%$ \\
\hline \multirow[t]{2}{*}{ Gender } & Male & 107 & 50 & $61 \%$ \\
\hline & Female & 107 & 32 & $39 \%$ \\
\hline \multirow{5}{*}{ Age } & $20-25$ & 107 & 8 & $10 \%$ \\
\hline & $26-35$ & 107 & 46 & $56 \%$ \\
\hline & $36-45$ & 107 & 19 & $23 \%$ \\
\hline & $46-55$ & 107 & 6 & $7 \%$ \\
\hline & 56- above & 107 & 3 & $4 \%$ \\
\hline \multirow{3}{*}{$\begin{array}{l}\text { Highest academic } \\
\text { qualification }\end{array}$} & Diploma or certificates & 107 & 9 & $11 \%$ \\
\hline & BA/BSC Degree & 107 & 66 & $80.5 \%$ \\
\hline & Master's Degree & 107 & 7 & $8.5 \%$ \\
\hline \multirow[t]{3}{*}{ Work Experiences } & $1-5$ & 107 & 36 & $44 \%$ \\
\hline & $6-10$ & 107 & 25 & $30.5 \%$ \\
\hline & Above 10 years & 107 & 21 & $26 \%$ \\
\hline \multirow{2}{*}{$\begin{array}{l}\text { Organizational } \\
\text { position }\end{array}$} & Management members & 107 & 6 & $7 \%$ \\
\hline & Non - Management & 107 & 76 & $93 \%$ \\
\hline
\end{tabular}

Source: Survey 2019

- Analysis of the variables

In response to the examination questions, four factors that refer to the critical components of namely BSC implementation, BSC for strategy execution \& communication tool, Performance measurement schedule analysis and challenges of BSC implementation in GCAB respectively were taken to structure the poll and dissect the reaction. These factors are among the significant achievement factors for compelling execution of the balanced scorecard. Hence, frequencies, percentages including proportions of focal inclination (the mean score method) were employed to examine the varieties inside the survey things.

For every variable, the researcher has figured out how to structure six to eight inquiries which expected to be better representing to the variable. Subsequent to embeddings the crude Likert scale data to SPSS 20, the reactions were examined and outlined by taking the mean score acquired under each inquiry to arrive the expressed variable.(BSC implementation, strategy execution \& communication cascading, Performance measurement and challenges of BSC), Hereunder are the questions under each variable and the analysis of the summarized responses for the questions.

- Organizational Readiness for BSC implementation

As per its maker, the "balanced-scorecard is built up by a procedure that assembles accord and lucidity about how to make an interpretation of the system into operational goals and measures. This implies the scorecard speaks to the aggregate learning of the directors of the organizations. The scorecard venture isn't an activity to improve an estimation framework but instead, to make changes in the manner the organization sees and oversees itself". (Norton,1992). Balance-scorecard to display an approach to deliberately quantify the arrangement of a company's human information and organizational capital-we call planed read availability without which even as well as cannot be expected succeed (Kaplan and Norton, 2004).

Thus, the organization tries to link performance management programs with its strategic goals and tactical 
objectives that scale up the concept of Balanced Scorecard. Therefore, exercising the technique becomes so difficult when critical care/ organizational readiness is not taken by everybody in the organizational community. BSC planning and implementation process is evaluation. The evaluation is expected to be conducted at individual, process and organizational level. Although the attempt to institutionalize evaluation system showed promising outcomes, the outcomes were not sufficient to bring significant change at different levels.

Accordingly, as table 4.2 shows, a minimum mean score of 2.90 (less than mean score of three) on the sufficiency of measures to represent each objective at the organizational level and the maximum mean score of 3.46 (greater than mean score of three) on designing frequency of data collection were registered. In this variable apart from "managers and employees are involved in the implementation which scored mean score of (2.90) respectively, the remaining performance measurement items of the balanced scorecard in this variable has been encouragingly representing the measurement of concurrence with a mean score of (3.21) and above.

Table 4.3 Summery on the BSC implementation

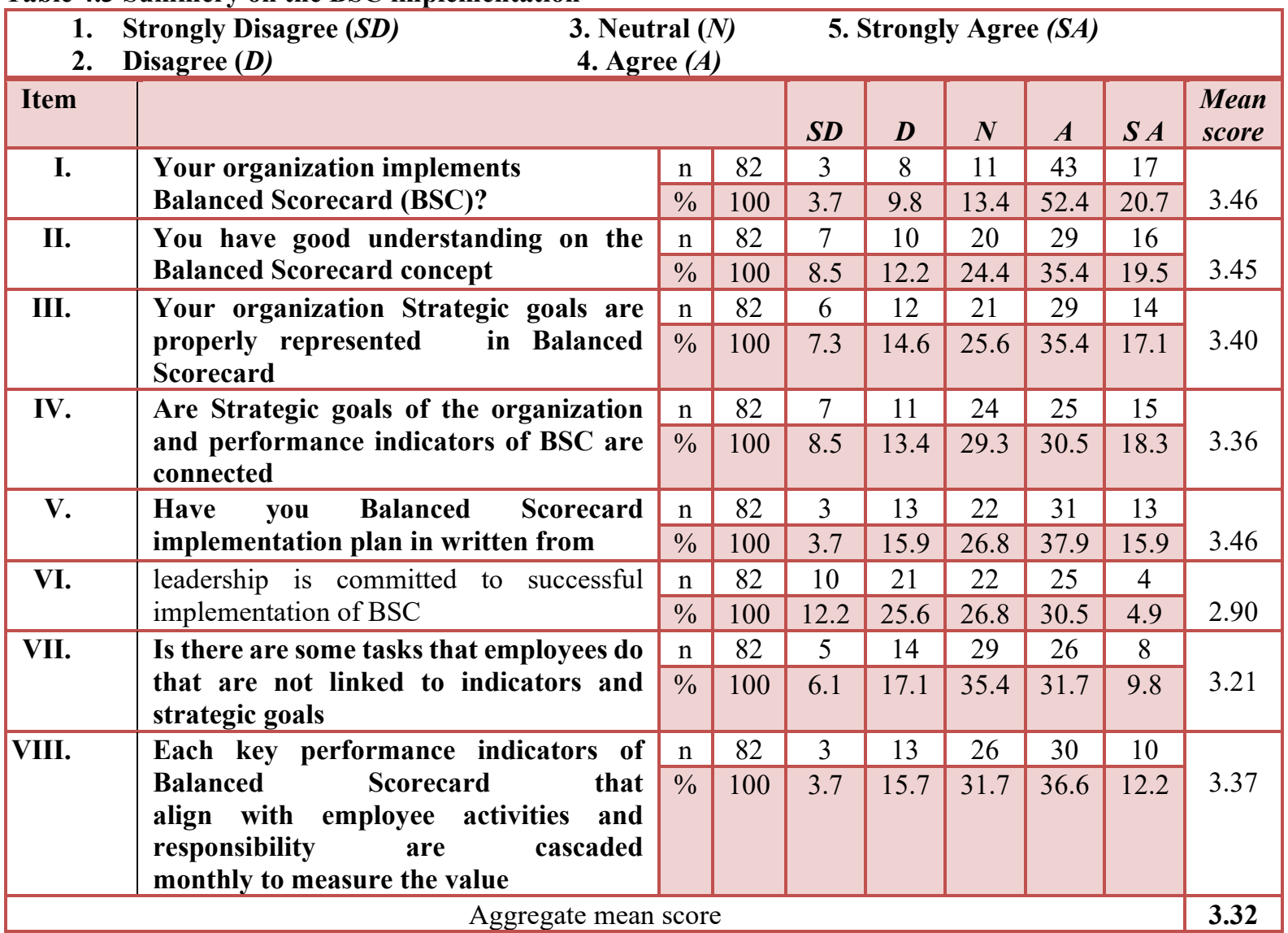

Source: Survey 2019

As shown under (Item-I), more than half of the respondents $73.2 \%$ agreed or strongly agreed, $13.4 \%$ remained neutral \& the rest $13.4 \%$ disagreed or strongly disagreed on the organization implements Balanced Scorecard in the GCAB. Thus, we can implement a Balanced Scorecard in the bureau high.

Under (Item-II), 55\% of respondents strongly agreed or agreed, $24 \%$ had doubts neutral and the rest $21 \%$ disagreed or strongly disagreed. They have a good understanding of the Balanced Scorecard concept. Hence, it can be drawn that there exists a gap in the bureau in understanding the Balanced Scorecard concept results or some partiality in doing so.

Concerning Strategic goals are properly represented in Balanced Scorecard with the bureau strategy, as depicted under (Item-III), more than half of the respondents 52\% agreed or strongly agreed, 26\% remained neutral, and $22 \%$ of them disagreed or strongly disagreed. This means, the bureau's effort to Strategic goals are properly represented in Balanced Scorecard is in a good condition. However, it is apparent that more effort is required to fully align the activities, as $48 \%$ of the respondents 'opinion reveals they are doubts neutral or disagree with the statement.

Under (Item-IV), majority (51\%) of the respondents had reservation and the rest $49 \%$ agreed or strongly agreed on the level of the Strategic goals of the organization and performance indicators of BSC are connected which revealed that the commitment level of management of GCAB in maintaining focus on both lag and lead indicates. 
Regarding the level of Balanced Scorecard implementation plan in writing form (Item-V) more than half of the respondents, $54 \%$ agreed or strongly agreed $19 \%$ remained neutral and $27 \%$ of them disagreed or strongly disagreed.

Under (Item-VI), level of commitment of GCAB's leadership for successful implementation of BSC in the bureau $29 \%$ agreed or strongly agreed, $27 \%$ remained neutral, and $38 \%$ disagreed or strongly disagreed. From this data, it can be concluded that the involvement and commitment of GCAB's leadership in implementing the BSC successfully are low and below expectation.

Concerning some tasks that employees do that are not linked to indicators and strategic goals as shown in (Item-VII), $42 \%$ agreed or strongly agreed, $35 \%$ remained neutral, and $23 \%$ disagreed or strongly disagreed. That means more than half of the respondents agreed not linked to BSC indicators and strategic goals.

As it can be seen from (Item-VIII), key performance indicators of Balanced Scorecard that align with employee activities and responsibility are cascaded monthly to measure the value $49 \%$ of respondents agreed or strongly agreed, $32 \%$ remained neutral, and $19 \%$ disagreed or strongly disagreed. Key performance indicators of Balanced Scorecard that align with employee activities and responsibility are cascaded monthly to measure the value.

\section{- $\quad$ BSC for strategy execution \& communication tool}

According to Kaplan and Norton (2001), to be effective, the BSC must be completely used at all dimensions in the organization, and the BSC must almost certainly make methodology "everybody's regular occupation". This mission can be accomplished through the communication and learning process; utilizing the correct procedure of building up personal and team objectives; and right linkages between performance, motivations and reward system.

Table 4.3 Responses' of the Employees on BSC for Strategy Execution \& Communication Tool

\begin{tabular}{|c|c|c|c|c|c|c|c|c|c|}
\hline \multicolumn{3}{|c|}{$\begin{array}{ll}\text { 1. Strongly Disagree }(S D) \\
\begin{array}{ll}\text { 2. Disagree } & (D)\end{array}\end{array}$} & \multicolumn{3}{|c|}{$\begin{array}{l}\text { 3. Neutral }(N) \\
\text { 4. Agree }(A)\end{array}$} & \multicolumn{4}{|c|}{ 5. Strongly Agree $(S A)$} \\
\hline Item & & & & $S D$ & $D$ & $N$ & $A$ & $S \boldsymbol{A}$ & $\begin{array}{l}\text { Mean } \\
\text { score }\end{array}$ \\
\hline \multirow[t]{2}{*}{ I. } & \multirow{2}{*}{$\begin{array}{l}\text { In my opinion the strategies are } \\
\text { implemented in actionable ways to } \\
\text { achieve GCAB long term vision. }\end{array}$} & $\mathrm{n}$ & 82 & 6 & 6 & 20 & 40 & 7 & \multirow[b]{2}{*}{3.40} \\
\hline & & $\%$ & 100 & 7.3 & 11 & 24.4 & 48.8 & 8.5 & \\
\hline \multirow[t]{2}{*}{ II. } & \multirow{2}{*}{$\begin{array}{l}\text { My institution strategy of } \\
\text { communication is primarily } \\
\text { interactive ( two way) }\end{array}$} & $\mathrm{n}$ & 82 & 3 & 16 & 13 & 36 & 14 & \multirow[b]{2}{*}{3.51} \\
\hline & & $\%$ & 100 & 3.7 & 19.5 & 15.9 & 43.9 & 17.1 & \\
\hline \multirow[t]{2}{*}{ III. } & \multirow{2}{*}{$\begin{array}{l}\text { I have clear line of sight among my } \\
\text { responsibilities } \\
\text {,accountability \& goals }\end{array}$} & $\mathrm{n}$ & 82 & 8 & 18 & 26 & 22 & 8 & \multirow[b]{2}{*}{3.04} \\
\hline & & $\%$ & 100 & 9.8 & 22 & 31.7 & 26.8 & 9.8 & \\
\hline \multicolumn{9}{|c|}{ Aggregate mean score } & 3.31 \\
\hline
\end{tabular}

Source: Survey 2019

The study result showed that the arithmetic means responses' of the employees on the overall situation of the bureau strategy execution \& communication tool considered in this study. The result shows the average means value of their response was 3.04 and 3.51 respectively which indicates that the majority of the respondents were positive replied on the implementation of strategies in an actionable way to achieve GCAB long term vision. The existence of two ways communication in the bureau, the majority of the respondents were disagreed their institution facilitate interactive two way of communication The table result shows the arithmetic mean and value of the respondents' believe on their level of understanding on the responsibilities, accountability \& goals in the bureau achievements were 3.51 respectively.

\section{- Performance measurement schedule analysis}

The balanced scorecard translates an organization's mission and strategy into a comprehensive set of performance measures that provides the framework for strategic measurement and system. The balanced scorecard retains an emphasis on achieving financial objectives but also includes the performance drivers of these financial objectives, the scorecard measures organizational performance across four perspectives; financial customers, internal business and growth (David P., 1996). 
Table 4.4 Responses' of the employees on Performance measurement schedule analysis

\begin{tabular}{|c|c|c|c|c|c|c|c|c|c|}
\hline & \multicolumn{2}{|l|}{$\begin{array}{l}\text { 1. Strongly Disagree }(S D) \\
\text { 2. } \quad \text { Disagree }(D)\end{array}$} & \multicolumn{3}{|c|}{$\begin{array}{l}\text { 3. Neutral }(N) \\
\text { 4.Agree }(A)\end{array}$} & \multicolumn{4}{|c|}{ 5. Strongly Agree $(S A)$} \\
\hline Item & & & & $S D$ & $D$ & $N$ & $A$ & $S A$ & $\begin{array}{l}\text { Mean } \\
\text { score }\end{array}$ \\
\hline \multirow[t]{2}{*}{ I. } & \multirow{2}{*}{$\begin{array}{l}\text { The measurement system } \\
\text { adequately corresponds to change } \\
\text { implementation plan under BSC }\end{array}$} & $\mathrm{n}$ & 82 & 7 & 19 & 25 & 25 & 6 & \multirow[b]{2}{*}{3.04} \\
\hline & & $\%$ & 100 & 8.5 & 23.3 & 30.5 & 30.5 & 7.3 & \\
\hline \multirow[t]{2}{*}{ II. } & \multirow{2}{*}{$\begin{array}{l}\text { BSC measures of performance are } \\
\text { directly linked to the strategic } \\
\text { objective of your organization }\end{array}$} & $\mathrm{n}$ & 82 & 6 & 15 & 19 & 32 & 10 & \multirow[b]{2}{*}{3.30} \\
\hline & & $\%$ & 100 & 7.3 & 18.3 & 23.2 & 39.0 & 12.2 & \\
\hline \multirow[t]{2}{*}{ III. } & \multirow{2}{*}{$\begin{array}{l}\text { In the process of implementing BCS } \\
\text { there is fertile ground that } \\
\text { employees take part in defining the } \\
\text { way their job will be measured }\end{array}$} & $\mathrm{n}$ & 82 & 10 & 15 & 25 & 25 & 7 & \multirow[b]{2}{*}{3.04} \\
\hline & & $\%$ & 100 & 12.2 & 18.3 & 30.5 & 30.5 & 8.5 & \\
\hline \multicolumn{9}{|c|}{ Aggregate mean score } & 3.12 \\
\hline
\end{tabular}

Source: Survey 2019

As shown under (Item-I), $38 \%$ the respondents agreed or strongly, $30 \%$ remained neutral \& the rest $32 \%$ disagreed or strongly disagreed or measurement system adequately corresponds to change implementation plan under $\mathrm{BSC}$ in the GCAB. As above $50 \%$ of the respondents 'opinion reveals they are doubts neutral or disagree with the statement.

Under (Item-II), BSC measures of performance are directly linked to the strategic are objective of the organization the respondents worked on $51 \%$ of respondents strongly agreed or agreed, $23 \%$ had doubts neutral and the rest $26 \%$ disagreed or strongly disagreed. $49 \%$ said the measures of performance are not directly linked to the strategic objective of their organization.

Concerning on employees' involvement in defining the way their job will be measured during BSC implementation, as depicted under (Item-III), the result shows of the respondents $39.02 \%$ agreed or strongly agreed, $30.49 \%$ remained neutral, and $30.49 \%$ of them disagreed or strongly disagreed. This means, Almost more than half of the entire respondents were indifferent whether employees involve or not.

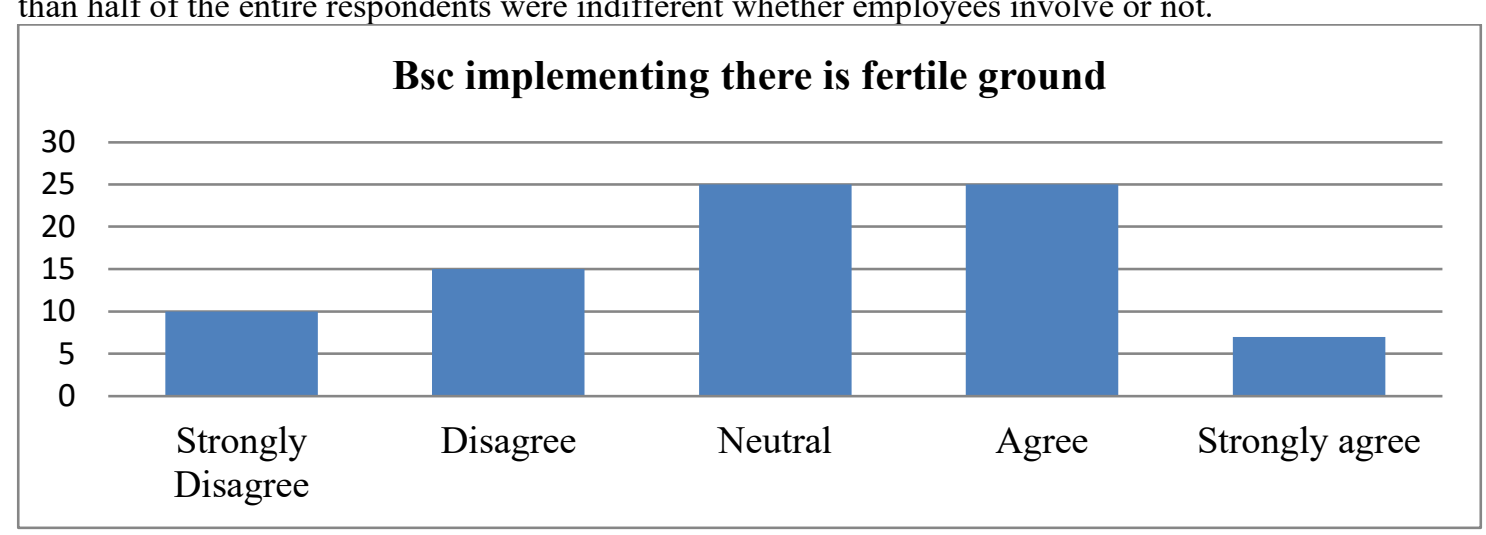

Source: Survey 2019

- Major Challenges of BSC Implementation GCAB

According to Kaplan and Norton (2007), BSC Implementation challenges are rooted in either poor design of the balanced scorecard or poor organization process. Poor design of the tool includes, failure to achieve balanced between the lagging and leading indicators and poor organization process includes inadequate BSC training, limited leadership involvement, minimum involvement middle and lower level stuff, inadequate or limited information technology support, poor planning, and non effective project teams.

These findings were then summarized and provided to respondents with a questionnaire along with other questions. The following table presents the major challenges prioritized/ranked from the most to the least serious in impeding the implementation process. 
Table 4.5 Respondents' rankings of major Challenges of BSC implementation in GCAB

\begin{tabular}{|c|c|c|c|c|}
\hline No & Factors/Challenges & Frequency & $\%$ & 華 \\
\hline 1 & $\begin{array}{l}\text { Lack of commitment, sense of ownership and less attention to } \\
\begin{array}{l}\text { customers }{ }^{6} \text { and employees }{ }^{6} \text { needs and expectations by management } \\
\text { members }\end{array}\end{array}$ & 35 & 43 & 1 \\
\hline 2 & Lack of empowerment, motivation, synergy, dedication etc. & 20 & 24 & 2 \\
\hline 3 & $\begin{array}{l}\text { Poor work system \& culture backed by bureaucratic \& delayed decision } \\
\text { making, etc. }\end{array}$ & 12 & 15 & 3 \\
\hline 4 & $\begin{array}{l}\text { Lack of civil service mentality, accountability, and resistance by non } \\
\text { management staff }\end{array}$ & 8 & 10 & 4 \\
\hline 5 & Poor office infrastructure and shortage of resources & 7 & 8 & 5 \\
\hline & Total & 82 & 100 & \\
\hline
\end{tabular}

Source: Survey 2019

As depicted in the table above, respondents have ranked the most serious challenges and impedimental factors for the fruitful execution of BSC in the bureau in accordance with their severity. Accordingly, it can be inferred that the gap in performance or the challenges related to BSC implementation on GCAB was mainly due to lack of commitment, felling of ownership and low level of response and focus by the bureau 's management to its internal and external stakeholders' concerns and expectations (ranked the most serious by $43 \%$ of respondents). The next top two most critical challenges include Lack of empowerment and motivation, poor office layout and poor work system \& culture backed by (bureaucratic \& delayed decision making) followed by resistance, lack of responsibility and accountability by non-management members, which can be the result of lack of close followup, supervision and monitory of the implementation process of BSC in the bureau.

In general, it can be inferred that weaknesses in management, lack of initiation among employees, poor motivating and innovative work environment and culture, weak effort to transform working conditions etc have adversely affected and contributed for the low-level success of the targets and the usage procedure of BSC in GCAB.

\section{Conclusions and Recommendations}

In this study, an attempt was made to examine the impact of BSC on the performance of public organization, particularly at Government Communication Affairs Bureau. The concept of Performance measurement, balanced scorecard and its four perspectives, features/principles, prospects, challenges, etc were also discussed with the help theoretical assertions and supported by empirical evidence.

A Standardized questionnaire with 19 questions organized in three themes in the five-point Likert scale was prepared and distributed to 82 respondents of the Bureau. While taking proportional stratified sampling to select respondents who are management and non-management employees implemented the balanced scorecard. Of the total 84 questionnaires, it was managed to collect 82 of them, i.e. a $98 \%$ response rate. Accordingly, the analysis was conducted by taking each variable. Each variable has three to eight questions that are suitably designed to measure the status of the variable and subsequently the survey analysis was made. The data were analyzed with the aid of descriptive statistics (percentage), mean and standard deviation. Based on the discussion of the data, the following summaries of findings are drawn: Based on the analysis, it has been managed to summarize the following findings:

For the institution to provide standard service, to be selective and to be competent, they should have passed many complicated and conditions. The design and preparation of stages of the reforms generally encouraging and up to standard with some irregularities and technical pitfalls especially in the BSC implementation and document preparation, The result of this study, Balanced Scorecard can be effectively implemented by undertaking different activities such as having strategic objectives that can be measured through BSC, providing awareness creation training to employees, providing feedback mechanisms and monitoring of activities. This will help organizations to be successful in meeting and strategies through helping employees to have a clear understanding of what is to be achieved. Though the 6 construction stages of BSC were done more or less appropriately, its implementation stages (cascading, automation and evaluation) were with gaps. This includes poor spiritual cascading, the inexistent of pocket cascading, the irregularities in cascading periodic plans to employees or giving regular feedbacks, and systems were not well automated. The evaluation of periodic reports of most departments was not BSC based as the reports usually lacks expressing performance in a single figure. The fact that the individual cascading formats reports lack of quality dimension to measure the cascaded activity primarily contributed to the mismatch between the employees and organizational evaluation results. Employees' perception of the impacts brought by the reform programs was mainly mixed with less clear pattern. Though employees were inclined to the positive impacts in improving participation, collaborative work sprit, capability and performance, most of them 
were its impact in changing their personal life like promotion and salary increment. But one should note that salary issue than an organization's affair in current context of the country.

BSC was reported to enhance the planning, reporting, and evaluation culture, enable every employee to clearly know the daily tasks, and boosted the alignment of daily exercises with the organizational strategies, vision, and mission. The study indicates that the commitment of the management in critical condition to implement the Balanced Score Card completely, so in this regard the management shall correct the drawback and give strong direction. There are a number of a staff member who has no full awareness and who have some awareness about balanced scorecards so in this regard to achieve the office vision and pan it is decisive to facilitate for creating full awareness of the staff member.

\section{Recommendations for Further Research}

Based on the major findings and conclusions reached by this study, the following recommendations have been forwarded. In this regard to make institutional change practical the management shall focus on identifying Key issues and work hard on the following issues.

The bureau of Management's should be primarily engaged in strategic issues rather than the unplanned ones. Frequent meetings of officials and employees have to be reduced and managed properly to save time for better service provision. Management at each level in the institution shall improve the gap in commitment, skill, and leadership quality and make research and studies to be carried out for the implementation of new and related systems.

In order to implement balanced scorecard, there shall be positive competition among the staff member. A clear guideline should be developed and made clear for employees to implement pocket cascading, In this regard there is a vast gap so if this is not implemented it shall have a negative influence on the staff of competency and efficiency, so attention shall be made. Reorganization for the value of one's work is an important factor in public service sector retention strategies. The bureau's management should use the BSC framework to align individual, team and process level accomplishments to the reward system. This enables the bureau to establish a ground for competition and best performance through motivation, recognition, and incentive.

The bureau shall focus on identifying to set the appropriate measurement tools that can evaluate the designed strategies result, goals and results that help to achieve the office vision. The implementation of change tools should not only be left for the management only it needs the participation of all staff. In this regard, the balanced score implemented in the bureau has the problem of implementing wit belief, integrity, and commitment. Besides, there are many staff member who has capacity gaps in their capacity, therefore, the effective way shall be facilitated with the management.

The studies have identified the main challenges for the implementation of balanced scorecard lack of sense of ownership, Lack of awareness, lack of attention to full fill staff member interest, Lack of self-development, limited participation, no efficient and effective decision, weak work culture, Conducive working environment, and lack of inputs so by challenging this effort has to be made for making the balanced score effective.

The implementation of change tools specifically BPR and BSC should not only be left for the reform coordinators. It should be embodied in the main structure and every department or head should follow up, evaluate and support his subordinates about the reform implementations. This is the main mechanism through which change tools are consistently implemented and getting assisted by them becomes a culture.

The Bureaus management's should improve periodic and need-based recalibration of their structures with full participation of implementers especially the lower level units who denied full participation in the first phase of the BSC implementation. The BSC should be used as a tool to channel energies and abilities of individual performers, team and process level operations through the establishment of motivating and creative work environment which is pillar and foundation of effective implementation of BSC.

The bureau has put in place properly designed and develop BSC manual which guides the entire process, from cascading to feedback. However, the root causes for the challenges in implementing the BSC originate from lack of follow-up and strict evaluation on a regular basis. Therefore, there should be a sound mechanism in place in the bank to undertake such responsibilities.

Mechanisms should be devised to enhance overall process and system automation in order to reduce the paper works and delays in BSC implementation. Without creating awareness and understanding about the concepts and objectives of BSC, it will be difficult both to the management and employees to internalize the concept and successfully accomplish its desired objectives, Improving the awareness level of both existing and newly entrant staff members through training and education by experts, consultants, and in collaboration with concerned institutions like Bureau of Civil Service to bridge the knowledge, attitude and skill gap.In The balanced scorecard system make the bureau to focus on the customer, the staff, strategies, and output and help the development of the office internal and external so for the implementation of this high commitment is required.

Finally, the bureau at different levels should periodically evaluate their status in implementing the reform tools and resulting outcomes in achieving the organizational mission. In doing so, the missing elements should 
continuously be improved so that the full impact of the reform can be realized and radical changed can be achieved.

This is not without implications for further research. The scope of the study could be expanded to include other public organizations. In the current study, data were collected only from Government Communication Affairs Bureau management and employees. The results could be more informative if the views other similar organizations were included and compared. At last, the researcher would like to recommend future researchers to further study the challenges of the balanced scorecard in research public organizations and private sector.

\section{REFERENCES:}

Adebabay, A. promoting and strengthening professionalism in the civil service: The Ethiopian case. Capacity Building workshop, Addis Ababa.: Promoting Professionalism in Public Service sector in Africa, 2011.

Anol Bhatacherjee. Social Science Research: Principles, Methods, and Practices: Florida: University of South Florida, 2012.

Artley Will, Ellison \& et.al . The Performance-Based Management handbook Laboratory Administration Office, volume-1,. California: university of California, 2001.

Balanced Scorecard institute. 1 28, 2019. https://www.balancedscorecard.org/BSC-Basics/About-the-BalancedScorecard (accessed 3 14, 2019).

Bedford, D. brown,D.A Malmi, and Sivabalan,P. "Balanced Scorecard Design and performance impacts." JAMAR, 6(2), 2008: 17-36.

Belnto, A. and White, L.F. "An Exploratory Study of Strategic performance Measurement System." Advances in Management Accounting, 18:1-26, 2010.

Bible L, kerr and S, Zanni M. "The balanced scorecard; here and back;." Management Accounting Q, Vo.17 No.4, 2006: 18-23.

C, r Kothari. Research Methodology Methods and Techniques 2nd edition. New Delhi: New Age international publishers, 2004.

David E, McNabb. Research Methods in Public Administration and Nonprofit Management. M.E. Sharpe, 2002.

Dire Dawa Administration Council. Proclamation, definition o fpowers and duties. Established and reestablishment of the executive and municipal service organs of the dire dawa administration. Dire Dawa: Dire Dawa Administration Council NO.10/2002 and NO 46/2016,, 2002.

Ethiopian Central Statistica Authority. Population and Housing Census Report and Estimation. Addis Abeba: Ethiopian Central Statistical Authority, ECSA, 2007.

Habtamu, Gezahenge. "Instructorse Perception of Performance Appraisal in Government Teachers Training Colleges of Amhara Region." Unpublished Master"s Thesis Addis Ababa University, Ethiopia, 2005.

Jay A. Conger and Ronald E. Riggio (Eds.). The practice of Leadership Developing the Next Generation of Leaders San Francisco California. California: Jossey-Bass, Inc., 2007.

Kaplan, R. S. and Norton D. P. . "The Execution Premium." Boston: Harvard Business School Publishing Corporation, 2008.

Kaplan, R. S. and Norton D. P. "Measuring the Strategic Readiness of Intangible Assets ." Harvard Business Review. , 2004: pp.2-3.

—. The Strategy Focused Organization. Boston, USA: HBS Press, 2000.

Kaplan, R. S. and Norton D. P. "Using the Balanced Scorecard as a Strategic Management System." Harvard Business Review Managing for the long term. (Harvard Business Review Managing for the long term.), 2007.

Kaplan, R. S. and Norton, D. P. "The balanced Scorecard-from strategy till bandling." Goteborg. ISL. Forlag., 1999.

Kaplan, R.S and Norton, D.P. "The Balanced Scorecard." Harvard Business School Press., 1996 a.

Kaplan, R.S and Norton, D.P. . "Using the Balanced Scorecard as a strategic management system." Harvard Business Review - on measuring corporate performance. Boston, MA: Harvard Business School Press, 1996: 183-211.

Kaplan, R.S and Norton, D.P. "The Balanced Scorecard - Measures that Drive Performance." Harvard Business Review, Vol. 70, no. 1,, 1992: pp,61-66.

Kaplan, R.S. and Norton, D.P. "Using the Balanced Scorecard as a Strategic Management System." Harvard Business Review, Vol.74, No.1,, 1996b: pp. 75-85.

Kaplan, R.S. "Conceptual Foundations of the Balanced Scorecard." Harvard University Working Paper 10-074 (Unpublished)., 2010.

Kaplan, R.S. "Strategic Performance Measurement in Non-Profit Organizations:." Nonprofit Management and Leadership,Boston, Massachusetts, 2001.

Tilaye Kassahun, "Civil Service Reform in Ethiopia: Achievements, problems and possible Solutions." Ethiopian Civil Service University, 2007.

Khomba, J. K. "Redesigning the Balanced Scorecard Model: An African Perspective." Unpublished, South Africa,University of Pretoria, 2011. 
Khomba, J. K. "Redesigning the Balanced Scorecard Model:An African Perspective. ." MA thesis, Pretoria,South Africa: University of Pretoria, 2011.

Kurechi, N. "Balanced Scorecard-Public Sector Organization." ICQI-Lohare, 2011.

Lonescu, M. Balanced Scorecard (BSc): Framework, Implementation Methodology and Recommended Application-Executive Brief. 4 12, 2012. http://www.balanced-scorecard.ro/does/Balanced Scorecard Executive Brief.pdf (accessed 2 28, 2019).

Maxwell, S., and Delaney, H. Designing experiments and analyzing data: A model comparison perspective (2nd Ed.). Mahwah: NJ: Lawrence Erlbaum Associates, 2004.

Mesfin Taffesse. "The Ethiopian Civil Service Reform Program In Taye Assefa (Ed.)." Digest of Ethiopia's National Policies, strategies and programs. FSS, Addis Ababa, 2009.

MoCS. "Civil Service Reform Program in Ethiopia: General Overview with Special Emphasis on Civil Service Reform Program." Ministry of Civil Service, Addis Ababa, 2012.

MoFED. "Annual Progress Report for FY 2010/11, ." Addis Ababa, Ethiopia, 2012.

Niven, P. R. Balanced Scorecard Diagnostics: Maintaining Maximum Performanc. New Jersey.: John Wiley \& Sons Inc., 2005.

_. Balanced Scorecard Step-by-Step Maximizing Performance and Maintaining Results (Second Ed.). Hoboken: John Wiley \& Sons, Inc., 2006.

—. Balanced Scorecard Step-By-Step: Maximizing Performance and Maintaining Results (1st Eds.). New York: John Wiley and Sons, Inc., 2002.

Norton, R.K. "The balanced scorecard-measures that drives performance." Harvard Business Revie, 1992 January-February.

Rashedul, Hasan. "Practical Application of Balanced Scorecard-A Literature Review." JSPM Vol 5 issue 3, 2017 : Abstract.

Robert V Krejcie and Daryle W Morgan's ;. "Determining Sample Size for Research." unpubilshed, 1970.

Rohm, H., Wilsey, D., stout, G. p., and Montgomery, D. The Institute Way Simplifying Strategic Planning and Management with the Balanced Scorecard. (First, Ed.). NC:: the institute press,cary, 2013.

Stemsrud hagen, J.I. "relevance in an Uncertain WorldThe Balanced Scorecard and Leadership: The Systems (ir) relevance in an Uncertain World." Work Paper No 23/03. SNF Project No 7872. ISSN 1503-, 2003.

Tamiru, F. "Organizational Factors, Achievements and Challenges of Implementing Reform Strategies in Addis Ababa City Administration:The Case of Three Selected Sector." Addis Ababa, Ethiopia, Civil Service University., 2013.

Tilaye, K. "Rethinking institutional excellence in Ethiopia : adapting and adopting the balanced scorecard (BSC) model." JBAS, 2(1): 22-53, 2010.

Umashev, C. and Willett, R. . "Challenges to Implementing Strategic Performance Measurement Systems in Multi-Objective Organizations The Case of a Large Local Government." Abacus, Vol 44, No.4, , 2008: pp.377-398.

United Nations. "A National Report on Progress made in the Implementation of the Beijing Platform for Action (Beijing + 10) Ethiopia." 2004: p.p1-2.

Van, W. "African Economies and the Politics of Permanent Crisis." Cambridge University Press., 2001.

Waal, A.D. "IS Performance Management Applicable in Developing Countries? TheCase of a Tanzanian College, ." International Journal of Emerging Markets, 2(1):, 2007: p.p 1-14.

Zikmund, W. G., Babin, B. J., Carr, J. C., and Griffin, M,. Business research methods (8th Ed.) . Mason: Ho: Cengage Learning, 2010.

\section{About Authors}

Esayas Debel Gelan was born in Dire Dawa, Ethiopia on 15 November, 1988. He studies high school in Sabiyan Secondary School, Dire Dawa in December 2005, and from the College of Micro Link Information Technology with a Bachelor of Arts in Business Administration in June 2014. He remained at the University of Beijing Normal to complete the Masters of Business Administration in June 2019.

My experience as a head of the different governmental organizations, my deep interest in support career as well as ambition to play my own role in the development of Dire Dawa Administration and the nation a whole inspires me to apply for publication the research.

I have more than 10 year's practical experience in Finance Officer, Vice-speaker, Head of Trade and Revenue Coordination and Executive Manager at different Bureaus. By now, I am serving in the Dire Dawa Administration Revenue Authority with the rank of higher expert in Tax administration. 